\title{
DOSAGEM DO FLUOR NAS ÁGUAS DE ABASTECIMENTO DE S. PAULO (*)
}

POR

\section{T. L. Araujo \\ Assistente}

A importância atribuida ao fluor no aparecimento duma série de sinais mórbidos para o lado dos dentes e dos ossos, levou nos últimos anos numerosos pesquisadores, principalmente americanos, a se preocuparem com os problemas da sua existência na água potavel e de sua ação sobre a economia animal. As experiências realizadas com animais de laboratório e com praticamente todas as espécies domésticas e tambem as observações de comunidades supridas por águas com teores diversos de fluor são concludentes e não deixam dúvidas quanto a ação dum excesso ou da escassês deste metalóide na dieta.

A bibliografia atual sobre o assunto é bastante vasta, mas nela não existem praticamente informações sobre nossas condições, no que diz respeito à existência do fluor em nossas águas. Parece-nos não terem sido feitas ainda dosagens de fluor mesmo nas águas que suprem as nossas grandes cidades como o Rio de Janeiro e S. Paulo, por exemplo. Isto nos levou a procurar determinar, num ensáio preliminar, o teor médio em fluor da água utilizada em São Paulo.

A justificativa do interesse em conhecer as quantidades de fluor ingeridas está no fato dele ser um constituinte constante de diversas partes do corpo como dos dentes e ossos, onde entra na proporção de 0,02 a $0,05 \%$. No entanto estas quantidades variam com o conteudo da alimentação. $\mathrm{O}$ excesso de fluor ingerido condiciona a perturbação dentária conhecida por "dentes manchados" e modificações esqueléticas como retardo na ossificação e grande transparência aos raios X. Trabalhos diversos como os de Trelles, Dean e Elvove indicam que águas contendo apenas 1,2 p.p.m. são suficientes para causàr as perturbações acima referidas, enquanto outros autores acham necessários índices mais altos como 2,4 p.p.m.. Por outro lado águas com teores excessivamente baixos em fluor, como 0,2 p.p.m. teem sido responsabilizadas pela maior incidência da cárie dentária, os dentes com cárie tendo na sua constituição, segundo ARMstrong e Breklus 62\% a menos de fluor que um dente normal. Em cidades como "Macomb" e "Quincy"

(*) Comunicado à Sociedade de Biologia de S. Paulo em 19-9-41. 
cujas águas conteem apenas 0,2 p.p.m. de $\mathrm{F}$ a cárie dentária é mais frequente que em "Calesburg" e "Monmouth" onde as águas conteem 1,7 e 1,8 p.p.m. do metalóide.

$\mathrm{O}$ gado bovino mostra-se muito sensivel à ingestão continuada de mais que 2 a $3 \mathrm{mg}$. de $\mathrm{F}$ por $\mathrm{kl}$. de peso. Inicialmente aparecem as costumeiras anomalias dentárias e ósseas, posteriormente a produção de leite diminue e o aparecimento de calores torna-se irregular. Em porcos foram tambem observadas alterações dos dentes. Dentre os animais domésticos os menos sensiveis aos efeitos do $\mathrm{F}$ estão as aves, pois, nestas requerem-se altos teores para que se produzam perturbações.

Usamos para nossas determinações do fluor na água o método de SANCHIS no qual foram introduzidas algumas modificações. (L. ARAUJo 1942). Em linhas gerais no método original o reativo empregado é o de zircónio-alizarina que age em meio ácido sobre uma série de padrões de fluor dando uma escala de cores com a qual é comparada a amostra em exame, após ter sido tratada pelo reativo.

Transcrevemos abaixo os resultados das análises que realizamos em águas de várias proveniências e que suprem São Paulo e aproveitamos o ensejo para agradecer ao Dr. C. DoREs da R.A.E. que gentilmente nos forneceu as amostras.

Água de Santo Amaro
a) In-natura
0,3 p.p.m.
b) Decantada
0,3 p.p.m.
c) Filtrada .
0,3 p.p.m.
d) Clorada (primeira descarga)
0,3 p.p.m.
e) Clorada (França Pinto).
0,3 p.p.m.

Água de Cotia
a) In-natura
0,3 p.p.m.
b) Decantada
0,3 p.p.m.
c) Filtrada .
0,3 p.p.m.
d) Clorada (Jaguaré)
0,2 p.p.m.
e) Clorada (Araçá)
0,2 p.p.m.

Água da Cantareira
a) Sem cloro (Junção)
0,3 p.p.m.
b) Clorada (Junção)
0,3 p.p.m.
c) Sem cloro (Cabuȩú)
0,3 p.p.m.
d) Clorada (Cabuçú)
0,3 p.p.m.
e) Clorada (Cabuçú)
0,3 p.p.m. 
Água de Rio Claro
a) In-natura
0,3 p.p.m.
b) Decantada
0,4 p.p.m.
c) Filtrada .
0,3 p.p.m.
d) Sem cloro
0,2 p.p.m.
e) Clorada
0,4 p.p.m.

Pelos dados supra vê-se que as águas de proveniências diversas que suprem S. Paulo teem de modo geral muito pouco fluor. Pode-se mesmo duvidar de que estas $0,3-0,4$ p.p.m. acusadas pelas poucas análises realizadas sejam só de fluor e não tambem de outras substâncias presentes na água e capazes de interferir na reação, embora o método usado seja tido como bastante sensivel. A ser verdadeira esta hipótese o teor médio em fluor seria ainda mais baixo, possivelmente 0,2 p.p.m. e São Paulo estaria em condições semelhantes as das cidades de "Macomb" e "Quincy", onde a incidência de cáries dentárias é bastante elevada, quando comparada com a de zonas onde a água dosa taxas mais altas de $\mathrm{F}$.

\section{Abstract}

The fluorine contents in the waters of the eity of São Paulo were found, in a preliminary test, to be very low.

\section{BIBLIOGRAFIA}

Araujo, T. L. - 1942 - Met. de dosagem do fluor na água - Rev. Fac. Med. Vet. S. Paulo - 2 (2).

Armstrong, W. D. - Breklus, P. J. - 1938 - J. Dental Research, 17:389-93.

Dean, H. F. - Elvove, L. - 1936 - Eng. News Record, 120:591-3.

FonseCA RIBEIro - 1941 - Cárie dentária, 52-8. São Paulo, Comp. Melhoramentos. MAYNARD, L. A. - 1937 - Animal nutrition, 156-61. New York, Me Graw-Hill Book Comp.

Trelles, R. A. - 1938 - Bol. Obras San. Nac., Buenos Aires, 2:367-9. 